\title{
STRATEGI PENINGKATAN KEPUASAN KONSUMEN JAHE SANG JAWARA DI MASA PANDEMI COVID-19 DENGAN PENDEKATAN IMPORTANCE PERFORMANCE ANALYSIS
}

\author{
IMPROVEMENT STRATEGY OF CONSUMER SATISFACTION SANG JAWARA GINGER IN COVID-19 \\ PANDEMIC USING IMPORTANCE PERFORMANCE ANALYSIS APPROACH
}

\author{
Arif Dzulfikar ${ }^{*}$, Siti Jahroh*), Mochammad Mukti Ali**) \\ *) Sekolah Bisnis, IPB University \\ Jl. Padjajaran, Bogor, Indonesia 16151, Indonesia \\ ${ }^{* *}$ Fakultas Ekonomi dan Bisnis, Universitas Mercu Buana \\ Jl. Meruya Selatan, Jakarta Barat 11650, Indonesia
}

\begin{abstract}
COVID-19 has major impact on human lives, the presence of this virus has made many people switch into healthy lifestyles. However, Arvan Natural Group, a startup company which produce instant ginger Sang Jawara has not taken advantage of this opportunity optimally. Therefore, the aim of this research is to evaluate the consumer satisfaction of ginger Sang Jawara in category of product, price, promotion, and service; and formulating strategies to increase consumer satisfaction. Data collection methods used are questionnaires and in-depth interviews with selected respondents. The sampling technique used is purposive sampling with the following criteria, consumers with an age range of 20-60 years, made purchases in the last three months, knowing the promotions and benefits of the products purchased. The number of samples obtained in this study are 42 respondents. The analysis tools used are the Customer Satisfaction Index (CSI) and Importance Performance Analysis (IPA). The results of the CSI analysis showed a value of $81.03 \%$. The results of the IPA analysis show that of the 21 measurement attributes, there are 5 attributes that are suggested to experience improvement. The attributes that are in quadrant I (top priority) are the product brand, size variations, colors, and promotional bonuses. The attributes in this quadrant are suggested to be corrected immediately by the company in order to meet the expectations of consumers. Meanwhile, in quadrant III, the attribute whose performance can be improved is special attention (empathy).
\end{abstract}

Keywords: COVID-19, lifestyle, IPA, instant ginger, consumer satisfaction

\begin{abstract}
Abstrak: COVID-19 telahberdampakbesarbagikehidupan manusia, adanya virusinimembuat banyak orang beralih ke gaya hidup sehat. Arvan Natural Group, salah satu perusahaan startup yang memproduksi jahe instan Sang Jawara, belum memanfaatkan peluang perubahan ini secara optimal. Maka dari itu, tujuan dari penelitian ini ialah ialah melakukan evaluasi kepuasan konsumen jahe Sang Jawara pada kategori produk, harga, promosi, serta pelayanan; dan melakukan penyusunan strategi peningkatan kepuasan konsumen. Metode pengumpulan data yang digunakan ialah penyebaran kuesioner dan wawancara mendalam dengan responden terpilih. Teknik pengambilan sampel yang digunakan ialah purposive sampling dengan kriteria sebagai berikut, konsumen dengan rentang umur 20-60 tahun, melakukan pembelian pada tiga bulan terakhir, mengetahui promosi dan manfaat dari produk yang dibeli. Jumlah sampel yang diperoleh dalam penelitian ini sebanyak 42 responden. Alat analisis yang digunakan ialah Customer Satisfaction Index (CSI) dan Importance Performance Analysis (IPA). Hasil dari analisis CSI menunjukkan nilai 81,03\%. Hasil analisis IPA menunjukkan dari 21 atribut pengukuran, terdapat 5 atribut yang disarankan untuk mengalami perbaikan. Atribut yang berada pada kuadran I (prioritas utama) ialah brand produk, variasi ukuran, warna, dan bonus promosi. Atribut pada kuadran ini disarankan agar segera diperbaiki oleh perusahaan agar dapat memenuhi ekspektasi dari konsumen. Sementara pada kuadran III, atribut yang kinerjanya dapat ditingkatkan ialah perhatian khusus (empathy).
\end{abstract}

Kata kunci: COVID-19, gaya hidup, IPA, jahe instan, kepuasan konsumen

${ }^{1}$ Corresponding author:

Email: arif.dzulfikar@gmail.com 


\section{PENDAHULUAN}

Gaya hidup merupakan profil dari keseluruhan pola hidup seseorang dalam kehidupan sehari-hari yang dapat terlihat dalam minat, pendapat, dan tindakan yang bersangkutan. Hal ini menunjukkan rupa keseluruhan pola perilaku seseorang dalam kehidupan seharihari (Kotler et al. 2005). Gaya hidup ini tercermin dari pilihan produk yang dipakai seseorang, pola penggunaan produk, dan tingkat kesenangan dari suatu produk yang dipilih. Contohnya saja seseorang yang memilih pola hidup sehat dan diet, tentunya pemilihan nutrisi makanan dan olahraga menjadi sangat penting (Hollensen, 2015).

Perubahan gaya hidup konsumen di Indonesia sudah terlihat dari tahun 2018, adanya indikasi data yang menjelaskan perubahan gaya hidup ke arah gaya hidup sehat. Berdasarkan data survei yang dilakukan oleh AIA (2018a), sebuah lembaga asuransi kesehatan internasional, dari tahun 2016 ke tahun 2018 telah terjadi peningkatan skor healthy living index sebesar 4 point menjadi 62. Skor indeks ini mencerminkan gabungan tingkat kepuasan kesehatan dan aktivitas berkegiatan sehat (olahraga, konsumsi makanan dan minuman sehat, pola tidur, pengecekan kesehatan, dan lainnya). Selain itu, menurut AIA (2018b), persepsi masyarakat Indonesia mengenai makanan atau minuman sehat memiliki harga lebih terjangkau dari tahun 2016 ke 2018 mengalami peningkatan sebesar 35\% menjadi $73 \%$.

Ditambah lagi dengan adanya peristiwa COVID-19yang muncul pada akhir tahun 2019, adanya penularan virus yang tergolong cepat dan berdampak negatif terhadap kesehatan membuat banyak masyarakat menjadi sadar bahwa gaya hidup sehat sangatlah penting. Adanya awareness yang meningkat menyebabkan masyarakat memilih untuk mengonsumsi makanan dan minuman sehat. Menurut BPS (2020), terjadinya kenaikan suplemen makanan sebesar 0,8 juta dari sebelum pandemi (Januari-Maret) ke setelah pandemi (AprilJuni) 2020. Selain itu, menurut Hidayat (2020), setelah pandemi global COVID-19 mulai muncul di Indonesia, hal ini menyebabkan terjadinya kenaikan permintaan secara signifikan pada tanaman biofarmaka, seperti jahe, temulawak, dan kunyit.
Arvan Natural Group merupakan perusahaan start-up yang bergerak dalam bidang kesehatan dan berdiri pada bulan Maret 2020. Produk yang dijual ialah produk jahe merah instan bubuk dengan merek "Sang Jawara". Komposisi produk ini terdiri dari jahe merah, gula, cengkeh, kayu manis, dan madu. Produk ini dikemas dalam kemasan toples plastik dengan berat 300 gram dan 340 gram. Jahe ini merupakan produk tradisional yang dipercaya dapat mencegah COVID-19. Menurut BPOM (2006), jahe memiliki kandungan yang dapat merangsang kekebalan tubuh manusia. Selain itu, menurut Harwati (2009), jahe memilki khasiat lainnya, seperti antimikrob, antioksidan, baik untuk pencernaan, dan radang sendi.

Dengan adanya peluang perubahan gaya hidup mengakibatkan adanya kenaikan permintaan produk herbal. Namun, perusahaan Arvan Natural Group terlihat belum mengoptimalkan peluang perubahan tersebut. Hal ini terbukti dari target penjualan sebesar $85 \%$ dari total produksi per bulan belum dapat dipenuhi oleh perusahaan. Hasil penjualan pun memperlihatkan masih terdapatnya fluktuasi pada beberapa bulan tertentu. Kondisi ini dapat disebabkan karena adanya persaingan pada industri yang sama mengalami peningkatan, jumlah pesaing dalam bidang industri jahe meningkat setelah adanya pandemi. Selain itu adanya potensi dari pendatang baru yang cukup besar untuk masuk ke bidang industri jahe. Disisi lain, dari sisi konsumen, pertumbuhan ekonomi yang negatif di kala pandemi menyebabkan terjadinya penurunan daya beli. Menurut Berita Remi Statistik (2020), pertumbuhan ekonomi Indonesia pada kuartal III 2020 mengalami minus sebesar $-3,49 \%$.

Adanya kondisi persaingan yang cukup ketat dan penurunan daya beli tentunya menyebabkan konsumen akan semakin selektif dalam memilih produk. Konsumen akan memilih produk yang berkualitas dengan harga terjangkau dan pelayanan terbaik; serta promosi yang dapat memikat hati konsumen. Maka dari itu, perusahaan perlu mengevaluasi keempat kategori tersebut dengan baik untuk memenuhi ekspektasi konsumen.

Ruang lingkup penelitian, survei konsumen dilakukan pada konsumen yang melakukan pembelian secara online dan memenuhi kriteria purposive sampling, yaitu konsumen dengan rentang umur 20-60 tahun, melakukan pembelian pada tiga bulan terakhir, serta mengetahui promosi dan manfaat produk yang dibeli. 
Perbedaan penelitian ini dengan penelitian lainnya terdapat pada kerangka pemikiran yang menggabungkan kategori product quality dari Garvin (1987), harga dan promosi berdasarkan Kotler dan Keller (2016), dan pelayanan dengan metode Service Quality dari Parasuraman et al. (1988). Dengan menggabungkan keempat kategori tersebut, perusahaan akan dapat menilai kepuasan konsumen secara komprehensif (luas dan menyeluruh). Kerangka pemikiran ini didasarkan pada penelitian terdahulu mengenai IPA pada kategori produk, pelayanan, dan penelitian yang telah menggabungkan beberapa kategori.

Penelitian terdahulu mengenai IPA pada kategori product quality telah dilakukan oleh Rahmanissa dan Sadeli (2016), Rahmasari et al. (2017), serta Al Safiq dan Fatmawati (2018). Ketiga penelitian ini berhasil mengevaluasi kepuasan konsumen pada produk minuman, atribut-atribut yang digunakan dalam pengukuran ialah rasa, aroma, kemasan, warna, manfaat, dan lain-lainnya. Dalampenelitian Rahmanissa dan Sadeli (2016) serta Al Safiq dan Fatmawati (2018) diperoleh permasalahan utama pada kuadran I (prioritas utama), yaitu atribut aroma minuman yang perlu mengalami peningkatan. Sementara itu, dalam penelitian Rahmasari et al. (2017) dengan objek minuman teh, penelitian ini menekankan perbaikan atribut pada kuadran III, hal ini dikarenakan faktor persaingan yang semakin ketat, sehingga perlunya perbaikan atribut variasi ukuran, kemasan, dan rasa sepat.

Penelitian lainnya mengenai IPA pada kategori pelayanan telah dilakukan oleh Yulia et al. (2016), Sutomo et al. (2017), Hendranata et al. (2017), dan Indrajaya (2018). Keempat penelitian ini berhasil mengukur dan mengevaluasi kualitas pelayanan dengan metode service quality (SERVQUAL). Dimensi yang digunakan pada keempat penelitian tersebut ialah responsiveness, reliability, empathy, assurance, dan tangibles. Dalam penelitian Sutomo et al. (2017) dan Hendranata et al. (2017) berhasil ditemukan permasalahan utama yang sama pada kuadran I, yaitu perlunya perbaikan responsiveness (ketanggapan dalam merespon suatu permasalahan). Sementara, dalam penelitian Yulia et al. (2016) terdapat dua permasalahan utama yang perlu segera diperbaiki, yaitu responsiveness (ketanggapan petugas) serta reliability (ketersediaan produk obat dan keberadaan petugas di tempat). Dalam penelitian lainnya, Indrajaya (2018), permasalahan utama terdapat pada empathy (pelayanan terhadap keluhan) dan assurance (keamanan).

Penelitian mengenai IPA yang menggabungkan beberapa kategori telah dilakukan oleh Nindiani et al. (2018) serta Yola dan Budianto (2013). Penelitian Nindiani et al. (2018) menggunakan kategori product quality dan pelayanan (SERVQUAL) untuk menilai kepuasan konsumen toko kue. Hasil dari penelitian ini menunjukkan atribut yang memerlukan perbaikan pada kuadran I; dari dimensi product quality ialah atribut rasa, perlunya formulasi resep baru; dari dimensi pelayanan ialah atribut keramahan, kinerja ini dapat ditingkatkan melalui pelatihan pegawai. Sementara, Yola dan Budianto (2013) menggabungkan kategori pelayanan dan harga produk. Hasilnya didapatkan permasalahan utama pada kuadran I, seperti kecepatan dan ketanggapan karyawan, keakuratan pembayaran, kenyamanan dan keamanan lokasi, potongan harga, serta harga pada beberapa produk unggulan yang belum bisa bersaing dengan kompetitor.

Alat analisis yang digunakan ialah Customer Satisfaction Index (CSI) dan Importance Performance Analysis (IPA). CSI ini merupakan metode untuk mengukur kepuasan pelanggan secara menyeluruh berdasarkan atribut-atribut yang telah ditentukan. Hasil persentase nilai CSI ini nantinya dapat dikategorikan menjadi tidak puas, kurang puas, cukup puas, puas, dan sangat puas.

Metode IPA ini dapat menilai gap antara kepentingan konsumen dengan kinerja perusahaan saat ini, sehingga perusahaan dapat menerapkan alternatif strategi pemasaran untuk memperbaiki atribut yang kurang memiliki kinerja baik. IPA dinilai dapat mengevaluasi kepuasan konsumen dengan biaya yang terjangkau dan mudah dimengerti oleh berbagai stakeholders (Martilla dan James 1977). Dengan perbaikan tersebut, diharapkan perusahaan dapat memiliki daya saing yang lebih tinggi, sehingga dapat memenuhi ekspektasi konsumen secara optimal dan memenangkan persaingan usaha yang terjadi.

Tujuan dari penelitian ini ialah melakukan evaluasi kepuasan konsumen jahe Sang Jawara pada kategori produk, harga, promosi, serta pelayanan; dan melakukan penyusunan strategi peningkatan kepuasan konsumen. 


\section{METODE PENELITIAN}

Penelitian ini dilakukan di perusahaan Arvan Natural Group yang bertempat di Ciomas Kabupaten Bogor. Waktu penelitian dimulai dari bulan September sampai dengan Desember 2020. Penelitian ini termasuk ke dalam penelitian deskriptif dengan pendekatan kuantitatif, yaitu metode survei yang dapat menilai tingkat kepentingan dan kinerja perusahaan. Data yang digunakan dalam penelitian ini ialah data primer dan data sekunder. Data primer diperoleh melalui metode survei dengan penyebaran kuesioner dan wawancara mendalam pada responden terpilih. Wawancara setelah penyebaran kuesioner dilakukan untuk mengetahui lebih rinci permasalahan yang ada dan ekspektasi perbaikan dari konsumen. Selain itu, data sekunder yang digunakan berasal dari data internal perusahaan (penjualan produk) serta data-data yang berkaitan dengan kondisi sosial, politik, dan ekonomi. Data-data tersebut dapat diperoleh melalui studi literatur yang berasal dari buku, website, artikel, dan jurnal.

Metode survei dilakukan dengan melakukan penyebaran kuesionerkepadarespondenterpilihdenganmenggunakan google form. Survei konsumen dibatasi pada konsumen yang melakukan pembelian produk jahe Sang Jawara secara online melalui market place (Tokopedia) dan sosial media (Whatss App, Facebook, Instagram). Hal ini dilakukan untuk memudahkan pengidentifikasian konsumen yang membeli jahe serta agar kategori pelayanan dapat diukur karena model penjualan Business to Costumer.

Teknik sampling yang digunakan dalam penelitian ini ialah purposive sampling dengan kriteria sebagai berikut konsumen dengan rentang umur 20-60 tahun, melakukan pembelian pada tiga bulan terakhir, mengetahui promosi dan manfaat dari produk yang dibeli. Kriteria rentang umur ini didasarkan pada database penjualan perusahaan yang menujukkan segmen pasar jahe Sang Jawara berada pada kalangan remaja hingga dewasa pada rentang umur 20-60 tahun. Alasan lainnya ialah untuk dapat memenuhi target sampel dikarenakan perusahaan ini masih dalam kategori start-up. Sementara, kriteria pembelian tiga bulan terakhir ini didasari agar konsumen masih mengingat dengan baik atribut kepuasan yang akan diukur perusahaan. Jumlah responden yang diperoleh dalam penelitian ini sebanyak 42 orang. Menurut Roscoe (1975), persyaratan jumlah responden dengan metode survei ialah minimal sebanyak 30 orang.

Langkah awal, kuesioner diuji validitas dan reliabilitas pada 30 responden awal untuk mengetahui keakuratan dan konsistensi dari pertanyaan. Setelah itu, penyebaran kuesioner dilakukan dan diperoleh hasil kuesioner dari 42 responden. Kemudian, data kuesioner ini diolah dengan metode Customer Satisfaction Index (CSI) dan Importance Performance Analysis (IPA). Rumus perhitungan CSI ini dimulai dengan mengalikan nilai rata-rata kepentingan dan kinerja masing-masing atribut (I X P). Kemudian hasil perkalian tersebut dijumlahkan keseluruhannya. Hasilnya dibagi dengan total nilai ratarata kepentingan atribut yang telah dikalikan 5, kemudian nilai akhir dikalikan $100 \%$.

Metode berikutnya, menurut Martilla dan James (1977), IPAdapatdigunakan sebagai alatuntuk melakukananalisis kesenjangan ( gap kinerja dan kepentingan) serta analisis kuadran. Analisis kuadran dimulai dengan menentukan dimensi-dimensi dan atribut yang akan digunakan dalam penelitian. Nilai kinerja dan kepentingan dihitung dengan skala linkert 1-5. Kemudian hasil masingmasing nilai atribut kinerja dan kepentingan akan dirataratakan, sehingga diperoleh nilai mean akhir. Atributatribut tersebut dipetakan kedalam diagram kartesius berdasarkan nilai mean kinerja (sumbu x) dan nilai mean kepentingan (sumbu y). Kemudian, sumbu garis $\mathrm{x}$ dan y dibuat berdasarkan hasil rata-rata keseluruhan atribut pada nilai kinerja dan kepentingan. Pada akhirnya, atribut dapat dipetakan ke dalam kuadran I (prioritas utama), kuadran II (pertahankan prestasi), kuadran III (prioritas rendah), dan kuadran IV (berlebihan).

Kerangka pemikiran ini dimulai dari perusahaan yang belum dapat memanfaatkan peluang perubahan gaya hidup akibat COVID-19 secara optimal. Hal ini terlihat dari hasil penjualan yang masih berada dibawah target $85 \%$ dari total produksi per bulannya. Maka dari itu, diperlukannya suatu evaluasi dengan menganalisis tingkat kepuasan konsumen. Evaluasi dilakukan menggunakan IPA, atribut dengan kinerja yang rendah akan diperbaiki dengan memberikan alternatif strategi peningkatan. Penelitian ini menggabungkan kategori product quality dari Garvin (1987), harga dan promosi berdasarkan Kotler dan Keller (2016), dan pelayanan dengan metode Service Quality dari Parasuraman et al. (1988) yang dijelaskan pada Gambar 1. Menurut Garvin (1987), pada product quality terdapat delapan dimensi kualitas, namun penelitian ini hanya menggunakan lima dimensi saja. Hal ini dikarenakan lima dimensi ini sesuai dengan karakteristik bisnis dan dapat dengan mudah dinilai oleh konsumen. Dimensi yang digunakan ialah performance (karakteristik utama produk), features 
(aspek pendukung), durability (ketahanan produk), aesthetics (prerferensi individu), dan perceived quality (brand, image produk). Menurut Kotler dan Keller (2016), promosi dan harga dapat terdiri dari beberapa dimensi, dimensi yang digunakan dalam penelitian ini untuk kategori harga ialah keterjangkauan harga produk. Sementara, dimensi yang digunakan untuk kategori promosi ialah konten promosi dan bonus promosi (diskon serta bonus barang). Menurut Parasuraman et al. (1988), kategori pelayanan dapat diukur dengan lima dimensi. Namun, penelitian ini hanya menggunakan empat dimensi saja, dimensi tangibles tidak diukur. Hal ini dikarenakan Arvan Natural Group tidak memiliki bentuk fisik tempat yang digunakan langsung untuk melayani konsumen. Empat dimensi lainnya yang diukur ialah responsiveness (layanan yang tanggap dan tepat), reliability (layanan tepat dan mandiri), empathy (kepedulian), dan assurance (pengetahuan dan kemampuan untuk dipercaya).

\section{HASIL}

\section{Uji Validitas dan Reliabilitas}

Validitas merupakan ukuran yang menunjukkan tingkat kevalidan atau ketepatan suatu instrumen dalam melakukan pengukuran (Umar 2003). Uji validitas dilakukan pada 30 responden awal untuk mengetahui validitas kuesioner sebagai instrumen penelitian. Hasil uji validitas pada 21 atribut (produk, pelayanan, promosi, dan harga) menunjukkan nilai $\mathrm{R}$ hitung $>\mathrm{R}$ tabel $(0,36)$, nilai $r$ tabel yang digunakan berdasarkan kriteria $\alpha=5 \%$ $\mathrm{dan} \mathrm{df}=28$. Maka dari itu, seluruh atribut dinyatakan valid untuk melakukan pengukuran tingkat kinerja dan kepentingan. Rincian uji validitas terdapat pada Tabel 1.

Reliabilitas dapat diartikan sebagai tingkat konsistensi hasil pengukuran pada pengujian yang dilakukan berulang kali (Azwar, 2007). Uji reliabilitas dilakukan pada 30 responden awal untuk mengetahui tingkat konsistensi hasil pengukuran. Hasil uji reliabilitas pada 21 atribut (produk, pelayanan, promosi, harga) menunjukkan nilai cronbach $\alpha>0,6$. Maka dari itu, seluruh atribut dinilai reliabel atau konsisten untuk melakukan pengukuran. Rincian uji reliabilitas terdapat pada Tabel 2.

\section{Profil Responden dan Limitasi Penelitian}

Total responden yang diperoleh sebanyak 42 orang, berdasarkan jenis kelamin, hasil kuesioner menunjukkan persentasejeniskelaminpriasebesar47,62\% danpersentase jenis kelamin wanita sebesar 52,38\%. Berdasarkan kelompok umur, hasil kuesioner menunjukkan besar presentase sebagai berikut, responden rentang umur 1825 tahun sebesar 11,9\%, responden rentang umur 26-35 tahun sebesar $42,86 \%$, responden rentang umur 36-45 sebesar 23,81\%, dan responden rentang umur 46-60 tahun sebesar $21,43 \%$. Hal ini menandakan peminat produk jahe Sang Jawara paling besar berada pada segmen umur 36-45 tahun. Namun, pada segmen muda, rentang umur 18-25 tahun jumlah peminat masih cukup sedikit.

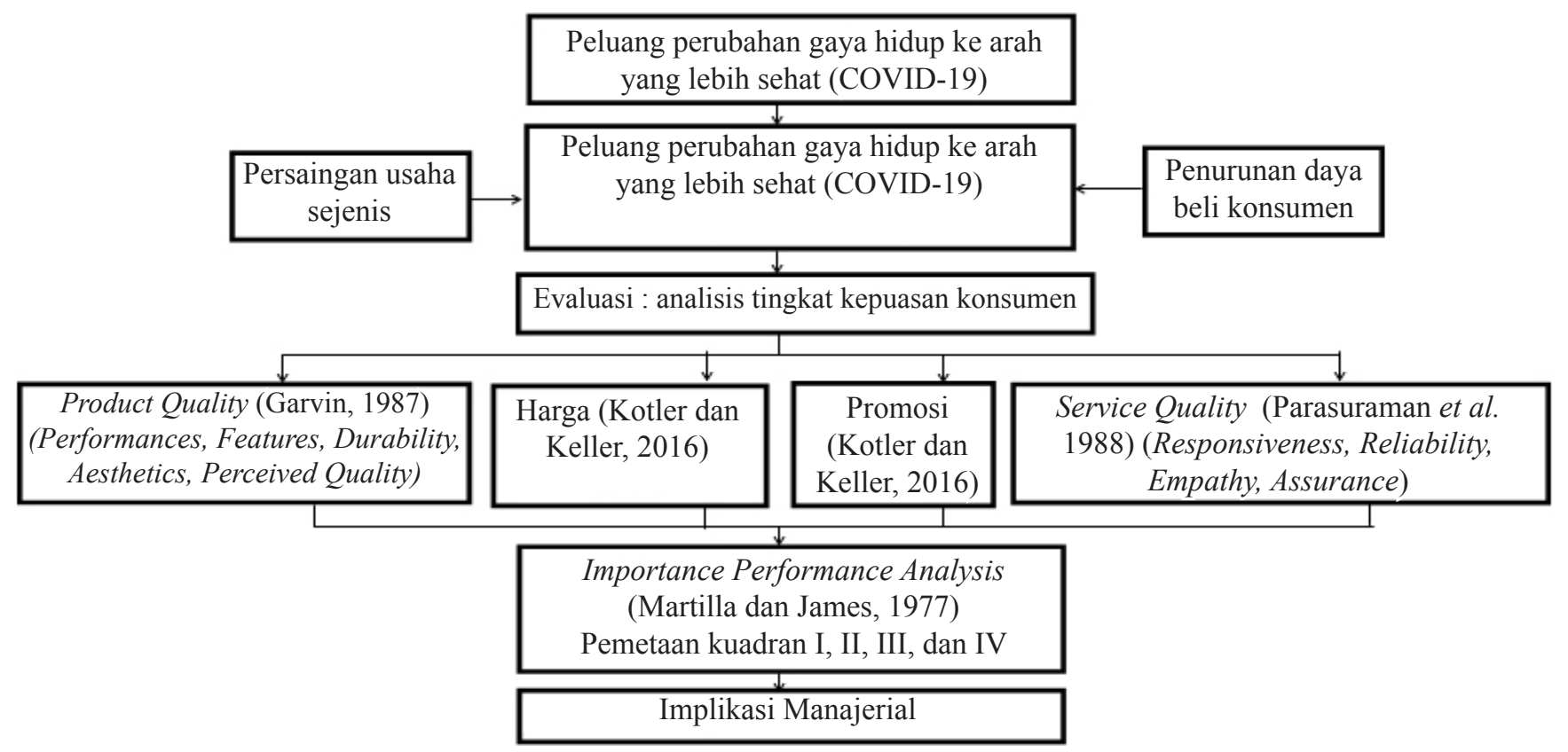

Gambar 1 Kerangka pemikiran penelitian 
Tabel 1. Hasil uji validitas kuesioner IPA

\begin{tabular}{lccc}
\hline \multicolumn{1}{c}{ Atribut } & R Hitung & R table & Uji Validitas \\
\hline Rasa & 0,43 & 0,36 & Valid \\
Kepedasan & 0,46 & 0,36 & Valid \\
Aroma & 0,50 & 0,36 & Valid \\
Warna & 0,71 & 0,36 & Valid \\
Tekstur & 0,44 & 0,36 & Valid \\
Manfaat & 0,62 & 0,36 & Valid \\
Kelengkapan Informasi & 0,44 & 0,36 & Valid \\
Variasi Ukuran & 0,73 & 0,36 & Valid \\
Ketahanan/ Durability & 0,40 & 0,36 & Valid \\
Bentuk dan Gambar Kemasan & 0,41 & 0,36 & Valid \\
Brand Produk & 0,63 & 0,36 & Valid \\
Harga & 0,63 & 0,36 & Valid \\
Konten Promosi & 0,46 & 0,36 & Valid \\
Bonus Promosi & 0,75 & 0,36 & Valid \\
Kecepatan dan Ketanggapan & 0,48 & 0,36 & Valid \\
Pelayanan Berkualitas & 0,37 & 0,36 & Valid \\
Ketepatan Waktu & 0,54 & 0,36 & Valid \\
Ketersediaan Produk & 0,55 & 0,36 & Valid \\
Keluhan Pelanggan & 0,71 & 0,36 & Valid \\
Perhatian Khusus & 0,76 & 0,36 & Valid \\
Keamanan Barang & 0,41 & 0,36 & Valid \\
\hline
\end{tabular}

Tabel 2. Hasil uji reliabilitas IPA

\begin{tabular}{|c|c|c|}
\hline Atribut & Nilai cronbach $\alpha$ & Uji Reliabilitas \\
\hline Rasa & 0,887 & Reliabel \\
\hline Kepedasan & 0,885 & Reliabel \\
\hline Aroma & 0,884 & Reliabel \\
\hline Warna & 0,877 & Reliabel \\
\hline Tekstur & 0,886 & Reliabel \\
\hline Manfaat & 0,881 & Reliabel \\
\hline Kelengkapan Informasi & 0,886 & Reliabel \\
\hline Variasi Ukuran & 0,876 & Reliabel \\
\hline Ketahanan/Durability & 0,887 & Reliabel \\
\hline Bentuk dan Gambar Kemasan & 0,886 & Reliabel \\
\hline Brand Produk & 0,881 & Reliabel \\
\hline Harga & 0,880 & Reliabel \\
\hline Konten Promosi & 0,886 & Reliabel \\
\hline Bonus Promosi & 0,875 & Reliabel \\
\hline Kecepatan dan Ketanggapan & 0,885 & Reliabel \\
\hline Pelayanan Berkualitas & 0,887 & Reliabel \\
\hline Ketepatan Waktu & 0,883 & Reliabel \\
\hline Ketersediaan Produk & 0,883 & Reliabel \\
\hline Keluhan Pelanggan & 0,877 & Reliabel \\
\hline Perhatian Khusus & 0,875 & Reliabel \\
\hline Keamanan Barang & 0,886 & Reliabel \\
\hline
\end{tabular}


Berdasarkan asal daerah pembelian, hasil kuesioner menunjukkan asal daerah responden berasal dari konsumen di wilayah Jabodetabek dengan persentase terbesar di daerah Bogor sebesar 54.76\%. Berdasarkan jenis pekerjaan, hasil kuesioner menunjukkan jumlah persentase terbesar didominasi oleh jenis pekerjaan pegawai swasta dengan persentase sebesar $47,62 \%$. Berdasarkan tingkat pendidikan, responden didominasi oleh jenjang lulusan S1 dengan persentase 57,14\%. Berdasarkan tingkat pendapatan, hasil kuesioner menunjukkan responden atau konsumen jahe Sang Jawara masih didominasi oleh kalangan menengah pada rentang pendapatan 3.000.000-5.000.000 rupiah sebesar $26,19 \%$ dan rentang pendapatan 5.000.0008.000 .000 rupiah sebesar $38.10 \%$. Limitasi penelitian ini ialah responden berada pada range umur yang cukup jauh 20-60 tahun, sehingga belum dapat mengungkapkan secara spesifik penilaian berdasarkan kategori kelompok usia remaja dan dewasa, kategori kelompok umur tersebut memungkinkan memiliki perspektif yang berbeda.

\section{Hasil Pengolahan Data Importance Performance Analysis}

Importance Performance Analysis dapat menilai tingkat kinerja suatu atribut dibandingkan dengan tingkat kepentingannya. Hasil yang didapat dari analisis ini dapat berupa analisis gap dan analisis kuadran. Dengan responden sebanyak 42 orang, diperoleh tabel kinerja dan kepentingan beserta analisis gap yang berada pada Tabel 3. Selain itu, analisis kuadran dapat digunakan untuk mengetahui posisi atribut, terdapat empat jenis kuadran, yaitu prioritas utama, pertahankan prestasi, prioritas rendah, dan berlebihan. Hasil dari analisis kuadran dapat dilihat pada diagram kartesius IPA Gambar 2.

Tabel 3. Analisis gap IPA

\begin{tabular}{|c|c|c|c|c|}
\hline Dimensi & Atribut & Kinerja $(\mathrm{P})$ & Kepentingan (I) & Gap (P-I) \\
\hline \multirow[t]{6}{*}{ Performance } & Rasa & 4,45 & 4,40 & 0,05 \\
\hline & Kepedasan & 4,26 & 4,21 & 0,05 \\
\hline & Aroma & 4,38 & 4,17 & 0,21 \\
\hline & Warna & 3,93 & 4,33 & $-0,40$ \\
\hline & Tekstur & 4,40 & 4,29 & 0,12 \\
\hline & Manfaat & 4,29 & 4,26 & 0,02 \\
\hline \multirow[t]{2}{*}{ Features } & Kelengkapan Informasi & 4,31 & 4,33 & $-0,02$ \\
\hline & Variasi Ukuran & 3,40 & 4,36 & $-0,95$ \\
\hline Durability & Ketahanan/Durability & 4,45 & 4,33 & 0,12 \\
\hline Aesthetics & Bentuk \& Gambar Kemasan & 4,29 & 4,36 & $-0,07$ \\
\hline Perceived Quality & Brand Produk & 3,36 & 4,33 & $-0,98$ \\
\hline Harga & Keterjangkauan Harga & 4,29 & 4,40 & $-0,12$ \\
\hline \multirow[t]{2}{*}{ Promosi } & Konten Promosi & 4,26 & 4,38 & $-0,12$ \\
\hline & Bonus Promosi & 4,12 & 4,38 & $-0,26$ \\
\hline \multirow[t]{2}{*}{ Responsiveness } & Kecepatan dan Ketanggapan & 4,50 & 4,36 & 0,14 \\
\hline & Pelayanan Berkualitas & 4,55 & 4,38 & 0,17 \\
\hline \multirow[t]{2}{*}{ Reliability } & Ketepatan Waktu & 4,55 & 4,33 & 0,21 \\
\hline & Ketersediaan Produk & 4,69 & 4,14 & 0,55 \\
\hline \multirow[t]{2}{*}{ Empathy } & Keluhan Pelanggan & 4,36 & 4,40 & $-0,05$ \\
\hline & Perhatian Khusus & 3,79 & 4,29 & $-0,50$ \\
\hline \multirow[t]{3}{*}{ Assurance } & Keamanan Barang & 4,55 & 4,21 & 0,33 \\
\hline & Nilai Rata-Rata & 4,25 & 4,32 & $-0,07$ \\
\hline & Customer Satisfaction Index & $81,03 \%$ & & \\
\hline
\end{tabular}




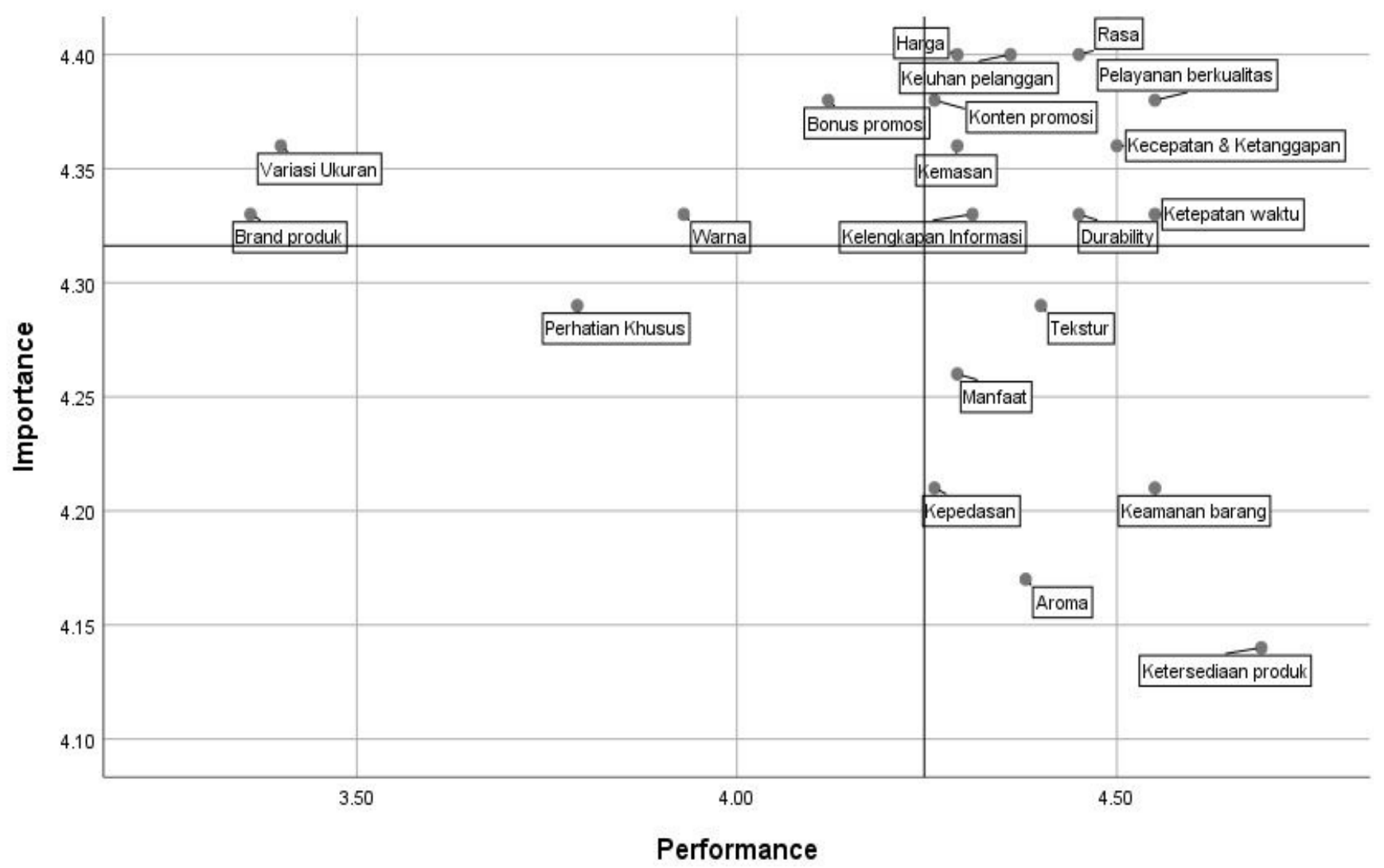

Gambar 2. Diagram kartesisus IPA produk jahe Sang Jawara

Hasil CSI produk jahe Sang Jawara ialah 81,03\%, berdasarkan kriteria yang telah umum diketahui, nilai ini menunjukkan secara keseluruhan konsumen sudah sangat puas. Namun tentunya masih terdapat atribut-atribut yang masih dapat ditingkatkan kembali kinerjanya untuk mencapai hasil CSI yang lebih tinggi. Berdasarkan tabel analisis gap, diperoleh atribut yang memiliki kesenjangan sangat tinggi, yaitu brand produk dengan gap 0,98 dan variasi ukuran dengan gap 0,95 . Atribut dengan gap yang tergolong sedang, yaitu perhatian khusus dengan gap 0,5, warna dengan gap 0,4, dan bonus promosi dengan gap 0,26 Maka, kelima atribut ini perlu segera diperbaiki oleh perusahaan agar dapat memenuhi ekspektasi konsumen. Penjelasan 21 atribut yang dipetakan dalam empat kuadran ialah sebagai berikut:

\section{Kuadran I (Prioritas Utama)}

Atribut dalam kuadran I dinilai penting oleh konsumen, namun perusahaan belum dapat memberikan kinerja yang lebih. Atribut pertama ialah brand produk, hal ini berkaitan dengan brand image produk yang belum baik, yaitu dalam tingkat kemudahan dikenali oleh masyarakat umum dan kepopuleran produk. Hal ini dikarenakan produk yang diluncurkan merupakan produk yang baru dan perusahaan Arvan Natural Group sendiri tergolong kategori start-up. Maka dari itu, perusahaan perlu menyusun strategi untuk meningkatkan brand image produk. Salah satu strategi yang sesuai ialah dengan kegiatan promosi dan iklan yang lebih intensif. Hal ini didukung oleh Maehle dan Supphellen (2013) dan Yunus (2016) yang menyatakan brand image dapat ditingkatkan dengan cara beriklan. Yunus (2016) menyatakan salah satu media yang baik dalam beriklan ialah television (TV) komersial, media ini telah berhasil meningkatkan brand image beberapa perusahaan market place. Sementara, Maehle dan Supphellen (2013) menekankan dalam beriklan sangat penting dilakukan dengan cara advertising alliances, yaitu beriklan dengan partner stakeholder lainnya untuk membentuk ciri yang positif. Menurut $\mathrm{Wu}$ dan Chen (2019), brand image suatu produk penting untuk diperkuat karena berpengaruh positif terhadap brand identification.

Cara lainnya untuk meningkatkan brand image dapat dilakukan melalui perizinan, sehingga reputasi dan kepercayaan konsumen meningkat. Perizinan yang ada tidak hanya diproses dan berada pada tingkat perizinan 
Pangan Industri Rumah Tangga (P-IRT), namun dapat ditingkatkan pada perizinan edar produk oleh BPOM dan perizinan produk halal. Hal ini didukung oleh penelitian dari Maulidah et al. (2014), yaitu legalitas produk yang baik dapat meningkatkan brand image suatu produk.

Variasi produk yang salah satunya dapat dikategorikan dengan ukuran memiliki pengaruh signifikan terhadap kepuasan konsumen (Lestari et al. 2019). Variasi ukuran merupakan aspek produk yang berperan terhadap kepuasan konsumen, kinerja yang rendah pada atribut ini dapat diperbaiki dengan membuat variasi ukuran kemasan yang lebih kecil atau besar dari ukuran yang sudah ada (Hermawan dan Solihin 2012). Atribut kedua ialah variasi ukuran, saat ini variasi ukuran hanya tersedia pada kemasan sedang saja, yaitu kemasan toples plastik 300 dan 340 gram. Maka dari itu, konsumen menginginkan variasi ukuran agar lebih banyak alternatif pilihan. Variasi ukuran dapat dibuat dalam bentuk sachet agar lebih praktis untuk konsumen karena tidak perlu menakar bubuk jahe. Selain itu, dapat pula dalam bentuk kemasan standing pouch, agar lebih dapat menyesuaikan dengan kebutuhan dan daya beli konsumen pada waktu-waktu tertentu.

Kualitas produk yang didalamnya terdapat aspek kinerja utama, seperti warna produk, rasa, dan lainnya berpengaruh positif terhadap kepuasan konsumen. Maka dari itu, standarisasi produk pangan penting untuk diperhatikan (Sembiring et al. 2014). Apabila suatu atribut warna produk pangan memiliki kinerja yang rendah dan tingkat kepentingan konsumen yang tinggi, maka perlunya perbaikan agar dapat menambah ketertarikan konsumen; perbaikan tersebut dapat dilakukan dengan mengevaluasi proses produksi yang telah berjalan (Kurniati et al. 2016; Efendi et al. 2018). Atribut ketiga yang dinilai ialah warna produk. Warna produk dari produk jahe Sang Jawara ini cenderung berwarna agak gelap dan cokelat. Sementara, konsumen menginginkan warna yang lebih cerah dan cokelat kemerahan, seperti produk jahe segar di gerai penjual. Tentunya dengan adanya proses pemanasan dan penguapan dalam pembuatan jahe bubuk membuat warna berbeda dari kondisi jahe ketika diolah secara segar. Maka, solusinya adalah dengan menambahkan zat pewarna alami pada proses mixing bahan, agar membuat tampilan warna lebih menarik.
Bonus pack (extra tambahan bonus) dan diskon memiliki pengaruh yang signifikan terhadap nilai hedonik (perasaan emosional ketika berbelanja). Kemudian nilai hedonik ini berpengaruh signifikan terhadap impulse buying (kegairahan dan spontanitas pembelian). Maka dari itu, penting untuk membuat diskon harga yang menarik dan bonus pack yang banyak dan bervariatif, agar akhirnya dapat meningkatkan ketertarikan konsumen untuk melakukan pembelian (Lestari, 2018). Atribut keempat ialah bonus promosi, dari perusahaan sendiri sudah memiliki bonus promosi, seperti adanya promo bebas biaya kirim. Promo ini tergolong efektif karena dapat mendominasi penjualan di market place (Tokopedia). Namun, dari hasil kuesioner dan wawancara, konsumen lebih menginginkan variasi bonus yang lebih beragam dan lebih banyak jenisnya. Hal ini terbukti dengan nilai harapan di bonus promosi cukup tinggi, yaitu 4,38. Maka dari itu, perusahaan dapat menambah bonus-bonus lainnya, seperti bonus aksesoris yang disesuaikan dengan segmen pasar, bonus perlengkapan kesehatan sesuai masa pandemi virus korona saat ini, atau bonus lain yang disesuaikan dengan event tertentu. Bonus promosi ini dapat berganti setiap bulannya, agar konsumen tidak mudah bosan dan lebih tertarik membeli produk.

\section{Kuadran II (Pertahankan prestasi)}

Atribut-atribut yang termasuk dalam golongan kuadran II perlu dipertahankan kinerjanya dikarenakan sudah dapat memenuhi ekspektasi konsumen (kinerja dan kepentingan bernilai tinggi). Pertama, atribut harga, konsumen menilai harga produk jahe Sang Jawara sudah terjangkau sesuai dengan berat jahe yang dijual dan kemasan yang digunakan. Kedua, atribut keluhan pelanggan, perusahaan selalu menanggapi keluhan dengan baik dan lengkap. Ketiga, atribut rasa, konsumen menilai rasa jahe dari produk jahe sangat terasa dan baik. Keempat, atribut konten promosi tergolong baik dikarenakan adanya design gambar yang menarik dan konten edukasi konsumen untuk mencegah virus korona.

Kelima, atribut kualitas pelayanan, konsumen menilai pelayanan sudah sangat berkualitas, Keenam, atribut kecepatan dan ketanggapan, perusahaan selalu memberikan respons yang cepat dan gesit apabila ada pertanyaan atau saran. Ketujuh, atribut bentuk dan gambar kemasan, konsumen menilai kemasan memiliki 
gambar yang menarik dan bentuk kemasan yang sesuai ekspektasi. Kedelapan, atribut durability, konsumen menilai produk ini dapat bertahan dalam jangka waktu yang lama. Kesembilan, atribut kelengkapan informasi, konsumen menilai produk sudah menyajikan informasi yang cukup lengkap, meliputi saran penyajian, manfaat, komposisi, dan info lainnya. Kesepuluh, atribut, ketepatan waktu, proses pengantaran barang ke konsumen selalu tepat pada waktunya.

\section{Kuadran III (Prioritas Rendah)}

Dimensi empathy (perhatian khusus) merupakan elemen yang penting. Kinerja yang rendah pada atribut ini perlu menjadi prioritas utama dalam perbaikan agar dapat memberikan kinerja yang memuaskan (Kusumo dan Sofyan, 2016). Dimensi empathy dengan kinerja yang rendah tersebut dapat diperbaiki dengan lebih memahami faktor-faktor yang menjadi kebutuhan pelanggan (Indrajaya, 2018). Penelitian lainnya dalam studi kasus toko online, empathy berpengaruh positif terhadap kepuasan pelanggan, indikator pembentuk empathy yang perlu diperhatikan diantaranya ketersediaan bantuan pelanggan dan adanya pertukaran pendapat atau adanya masukan dari pelanggan (Setiyaningrum dan Hidayat, 2016). Aspek Atribut yang termasuk dalam kuadran III ialah atribut perhatian khusus (empathy). Kuadran III menjelaskan atribut memiliki kinerja yang rendah dengan tingkat kepentingan dari konsumen yang juga rendah, sehingga atribut ini tidak menjadi prioritas utama. Namun, tentunya untuk berjaga-jaga, perusahaan tetap perlu memerhatikan atribut ini dikarenakan sewaktu-waktu ekspektasi dari konsumen dapat bergeser. Berdasarkan wawancara, perusahaan dapat memberikan extra services yang diinginkan konsumen pada pelayanan, yaitu berupa pemberian kiat-kiat kesehatan untuk konsumen jahe Sang Jawara, seperti penjelasan pola hidup sehat yang lebih terperinci lagi. Hal ini tentunya akan menambah rasa empathy dari para konsumen.

\section{Kuadran IV (Berlebihan)}

Atribut yang termasuk dalam kuadran IV telah melebihi ekspektasi atau harapan dari konsumen, yaitu kinerja bernilai tinggi sementara kepentingan bernilai rendah. Pertama, atribut ketersediaan produk, produk selalu tersedia ketika dipesan oleh konsumen. Hal ini dikarenakan perusahaan selalu memiliki stok persediaan lebih. Kedua, atribut aroma, bau harum jahe sangat terasa oleh konsumen. Ketiga, atribut kepedasan, menurut konsumen rasa pedas jahe sudah terasa dengan baik. Keempat, atribut manfaat, konsumen merasakan manfaat yang baik setelah meminum jahe Sang Jawara. Kelima, atribut keamanan barang, barang selalu sampai pada tujuan dengan aman dan baik. Hal ini dikarenakan perusahaan memiliki packaging dengan karton berlapis dan bubble wrap, sehingga barang selalu aman di perjalanan. Keenam, atribut tekstur, konsumen menilai bubuk jahe sudah sangat halus dan berkualitas baik.

\section{Implikasi Manajerial}

Implikasi teoritis dari penelitian ini ialah dalam pengukuran kepuasan pelanggan dapat diperhatikan dari berbagai macam kategori, seperti produk, harga, promosi dan pelayanan. Hal ini dimaksudkan agar didapatkan hasil analisa yang komprehensif, sehingga dapat lebih memahami kekurangan yang perlu diperbaiki disuatu perusahaan. Implikasi praktis dari penelitian ini ialah perusahaan perlu merumuskan alternatif strategi baru untuk meningkatkan kinerja atribut pada kuadran I dan III. Pada kuadran I atributatribut yang memerlukan perbaikan ialah brand produk, variasi ukuran, warna produk, dan bonus promosi.

Pertama, brand produk jahe Sang Jawara masih belum populer dan dikenal baik di masyarakat. Maka dari itu, strategi yang disarankan ialah penetrasi pasar, strategi ini merupakan kegiatan peningkatan pangsa pasar melalui suatu kegiatan pemasaran yang lebih besar. Kegiatan ini dilakukan melalui promosi yang lebih intens dan menjangkau lebih banyak target pasar di wilayah Jabodetabek. Perusahaan dapat menambah budget iklan untuk meningkatkan intensitas promosi di market place dan sosial media. Promosi ini berisi keunggulan dan keunikan produk jahe Sang Jawara. Promosi di market place dapat dilakukan melalui platform tokopedia ads, sementara untuk sosial media dapat digunakan fitur facebook ads, instagram ads, dan lainnya. Selain itu, perusahaan juga perlu mengikuti pameran dan event promosi produk start-up secara rutin, agar produk lebih dikenal baik di masyarakat.

Kedua, permasalahan variasi ukuran, konsumen jahe Sang Jawaradidominasiolehkalanganmenengah dengan rata-rata rentang pendapatan mulai dari 3.000.0005.0000 rupiah dan 5.000.000-8.0000 rupiah. Dengan kondisi pandemi COVID-19 saat ini menyebabkan pertumbuhan ekonomi negatif, sehingga sangat memengaruhi konsumen di kalangan kelas menengah; adanya penurunan daya beli akibat pemotongan intensif, 
penurunan penjualan bagi yang berwirausaha, dan lainlain. Saat ini, perusahaan menjual produk utama jahe merah 300 gram dengan kemasan toples pada kisaran harga 27.000-30.000 rupiah. Maka, dengan adanya variasi ukuran melalui kemasan standing pouch 150 gram dengan kisaran harga 13.000-15.000 rupiah dan kemasan sachet 18 gram dengan kisaran harga 2.0003.000 rupiah, diharapkan dapat menyesuaikan dengan daya beli konsumen saat ini.

Ketiga,permasalahan warna produk, tentunyakonsumen menginginkan produk dengan warna yang memikat dan menarik. Perusahaan dapat memperbaikinya dengan menambah zat pewarna dari ekstrak alam yang berwarna merah, seperti secang dan bunga rosella, agar produk bewarna lebih cerah dan coklat kemerahan. Penambahan zat warna ini berasal dari bahan yang memiliki keamanan pangan sangat baik.

Keempat, permasalahan tingkat kemenarikan bonus promosi, dari konsumen menginginkan bonus yang lebih bervariatif lagi, tidak hanya bonus yang berfokus pada potongan harga. Perusahaan dapat memberikan bonus barang yang dibutuhkan saat masa pandemi ini, seperti masker, handsanitizer ukuran kecil, faceshield dan lain-lainnya. Selain itu, bonus lainnya dapat berupa aksesoris-aksesoris yang digemari kaum wanita dan kalangan muda. Skema bonus ini dapat diberikan bagi pelanggan yang telah beberapa kali membeli produk jahe ataupun bonus diberikan ketika terdapat kegiatankegiatan penting tertentu sebagai sarana promosi produk.

Kelima, pada kuadran III, terdapat atribut perhatian khusus (empathy), atribut ini memiliki kinerja yang rendah dan tingkat kepentingan konsumen yang rendah. Namun, untuk mengantisipasi perubahan ekspektasi konsumen yang dapat berubah pada waktu tertentu, ada baiknya perusahaan dapat meningkatkan kinerja pada atribut ini. Perusahaan dapat memberikan extra services, seperti kiat-kiat kesehatan yang lebih detail. Perusahaan dapat lebih menjelaskan secara rinci jumlah porsi minuman jahe yang baik diminum bagi penderita penyakit-penyakit tertentu. Selain itu, penjelasan mengenai pola olahraga, pola konsumsi minuman dan makanan sehat, serta tambahan informasi kesehatan lainnya yang dibutuhkan saat pandemi virus korona ini. Dengan cara tersebut diharapkan dapat menumbuhkan rasa empathy dari konsumen, sehingga tercipta hubungan yang baik.

\section{KESIMPULAN DAN SARAN}

\section{Kesimpulan}

Hasil dari analisis Customer Satisfaction Index menunjukkan nilai $81,03 \%$. Hasil analisis Importance Performance Analysis menunjukkan adanya peluang perbaikan pada beberapa atribut pada kategori produk, pelayanan, dan promosi. Kategori produk, atributatribut yang dapat termasuk prioritas utama perbaikan ialah brand produk, variasi ukuran, dan warna produk. Dari atribut brand, perusahaan dapat meningkatkan brand produk dengan cara melakukan iklan dan promosi secara rutin. Dari atribut ukuran, perusahaan dapat memberikan alternatif berbagai variasi ukuran untuk dapat menyesuaikan dengan selera dan kondisi daya beli konsumen. Sementara, dari atribut warna produk, adanya penambahan ekstrak bahan alami dapat membuat warna produk lebih cerah dan berwarna cokelat kemerahan. Kategori pelayanan, atribut yang dapat diperbaiki ialah perhatian khusus (empathy). Perusahaan dapat lebih memberikan extra services, seperti kiat-kiat kesehatan mengenai pola hidup sehat di masa pandemi secara terperinci dan jelas. Kategori promosi, atribut yang dapat diperbaiki ialah bonus promosi. Perusahaan dapat memberikan bonus promosi yang lebih beragam lagi jenisnya dan berganti-ganti disesuaikan dengan selera konsumen. Dengan perbaikan pada ketiga kategori tersebut diharapkan ekspektasi konsumen dapat terpenuhi dengan sangat baik, sehingga market share produk jahe dapat meningkat.

\section{Saran}

Perusahaan perlu melakukan evaluasi dan perbaikan pada kategori produk, pelayanan, promosi, dan harga secara berkelanjutan. Dengan kinerja yang baik pada keempat kategori tersebut diharapkan akan berdampak pada loyalitas pelanggan serta penambahan konsumen baru, sehingga meningkatkan market share produk. Saran untuk penelitian selanjutnya, perusahaan dapat melakukan analisis preferensi konsumen jahe berdasarkan rentang kelompok umur yang lebih spesifik. Analisis yang menarik untuk dilakukan ialah preferensi konsumen pada generasi muda (Generasi Z) untuk mengetahui pandangan, tingkat minat, serta kepuasan terhadap produk tradisional jahe. 


\section{DAFTAR PUSTAKA}

AIA. 2018a. The AIA Healthy Living Index 2018. Shanghai: AIA Group Limited.

AIA. 2018b. Riset AIA healthy living index. http:// www.aia-financial.co.id. [28 Mei 2020]

Al Safiq F, Fatmawati EW. 2018. Analisis kepuasan konsumen sari buah belimbing manis (arverrhoa carambola L) (studi kasus di UD Cemara Sari Kelurahan Karangsari kecamatan Sukorejo kota Blitar). VIABEL: Jurnal Ilmiah Ilmu-Ilmu Pertanian 12(2):20-31.https://doi.org/10.35457/ viabel.v12i2.496

Azwar S. 2007. Reliabilitas dan Validitas. Yogyakarta: Pustaka Pelajar.

Berita Resmi Statistik. 2020. Galeri infografis. https:// www.bps.go.id. [21 November 2020]

BPOM. 2006. Serial Tanaman Obat, Jahe. Jakarta: Badan Pengawas Obat dan Makanan.

BPS. 2020. Analisis Big Data di Tengah Masa Adaptasi Kebiasaan Baru. Jakarta: Badan Pusat Statistik.

Efendi Z, Silvia E, Wijaya RR. 2018. Analisis kinerja dan kepentingan pada atribut keripik beledang Bengkulu sebagai upaya pengukuran kualitas kepuasan pada industri makanan. Jurnal Agroindustri 8(1): 26-33.https://doi. org/10.31186/j.agroind.8.1.26-33

Garvin DA. 1987. Competing on the eight dimensions of quality. https://hbr.org. [10 Oktober 2020].

Harwati TC. 2009. Khasiat jahe bagi kesehatan manusia. Jurnal Inovasi Pertanian 8(1):5 54-61.

Hendranata R, Ma'arif MS, Kirbrandoko. 2017. Bauran pemasaran dan kepuasan konsumen agen laku pandai PT. Bank XYZ. Jurnal Aplikasi Bisnis dan Manajemen 3(3): 398-406.https://doi. org/10.17358/jabm.3.3.398

Hermawan M, Solihin S. 2012. Usulan strategi pemasaran produk garam (studi kasus: produk garam karya tani). Integra-Jurnal Teknik dan Manajemen Industri 2(1): 77-94.

Hidayat AAN. 2020. Permintaan tinggi, harga jahe, kunyit, temulawak terus naik. https://bisnis. tempo.co. [22 November 2020].

Hollensen S. 2015. Marketing Management, A Relationship Approach. Ed. ke-3. Harlow: Pearson Education Limited.

Indrajaya D. 2018. Analisis kualitas pelayanan terhadap tingkat kepuasan konsumen menggunakan metode importance performance analysis dan customer satisfaction index pada UKM gallery. IKRA-ITH TEKNOLOGI: Jurnal Sains \&
Teknologi 2(3): 1-6.

Kotler P, Keller KL. 2016. Marketing Management. Ed. ke-15. Harlow: Pearson Education Limited.

Kotler P, Wong V, Saunders J, Amstrong G. 2005. Principles of Marketing. Ed ke-4. Harlow: Pearson Education Limited.

Kurniati E, Silvia E, Efendi Z. 2016. Analisis kepuasan konsumen terhadap kue baytat Bengkulu. Jurnal Teknologi dan Industri Pertanian Indonesia 8(2): 67-75. https://doi.org/10.17969/jtipi.v8i2.6784

Kusumo PA, Sofyan S. 2016. Strategi peningkatan kualitas pelayanan jasa dengan menggunakan metode IPA (Importance-Performance Analysis) pada AHASS 01108 Anugrah Jaya Semarang. Diponegoro Journal of Management 5(1): 1-14.

Lestari ENF, Hidayat Z, Budiwati H. 2019. Pengaruh variasi produk dan servicespace terhadap kepuasan konsumen (studi kasus pada Rocket Chicken di Lumajang). Jobman: Journal of Organization and Bussines Management 2(1): $16-19$.

Lestari SIP. 2018. Pengaruh price discount dan bonus pack terhadap impulse buying melalui nilai hedonik di Carrefour Surakarta. Jurnal Maksipreneur: Manajemen, Koperasi, dan Entrepreneurship 7(2): 129-140. https://doi. org/10.30588/jmp.v7i2.362

Maehle N, Supphellen M. 2013. Advertising strategies for brand image repair: The effectiveness of advertising alliances. Journal of Marketing Communications 21(6): 1-13. https://doi.org/10. 1080/13527266.2013.866594

Martilla JA, James JC. 1977. Importance-performance analysis. Journal of Marketing 411(1): 77-79. https://doi.org/10.1177/002224297704100112

Maulidah S, Santoso H, Yudhi F. 2014. Peningkatan brand image (citra merek) dalam rangka pengembangan produk agroindustri kering kentang (Studi kasus pada kering kentang "Kirana" di Kabupaten Tuban). SEPA: Jurnal Sosial Ekonomi Pertanian dan Agribisnis 11(1): 98-109. https://doi.org/10.20961/sepa. v11i1.14158

Nindiani A, Hamsal M, Purba HH. 2018. Product and service quality analysis: an empirical study of customer satisfaction in a bakery. Binus Business Review 9(2): 95-103.https://doi.org/10.21512/ bbr.v9i2.4257

Parasuraman A, Zeithaml VA, dan Berry LL. 1988. Servqual: A multiple-item scale for measuring perceptions of service quality. Journal of 
Retailing 64(1): 12-40.

Rahmanissa R, dan Sadeli AH. 2016. Kepuasan konsumen terhadap atribut kualitas minuman kopi di Java Preanger Coffee House Bandung. Agricore: Jurnal Agribisnis dan Sosial Ekonomi Pertanian 1(1): 54-61. https://doi.org/10.24198/ agricore.v1i1.22690

Rahmasari LF, Nurmalina R, Priatna WB. 2017. Analisis sikap, konsistensi dan kepuasan pada Teh Kotak Ultrajaya: Aan experimental marketing research on IPB agribusiness master of science students. Forum Agribisnis 7(1): 85-102. https://doi. org/10.29244/fagb.7.1.85-102

Roscoe JT. 1975. Fundamental Research Statistics for The Behavioural Sciences. Ed. ke-2. New York: Holt Rinehart \& Winston.

Sembiring IJ, Suharyono, Kusumawati A. 2014. Pengaruh kualitas produk dan kualitas pelayanan terhadap kepuasan pelanggan dalam membentuk loyalitas pelanggan (Studi pada pelanggan McDonald's MT. Haryono Malang). Jurnal Administrasi Bisnis 15(1): 1-10. https://doi. org/10.46369/logistik.v10i1.691

Setiyaningrum A, Hidayat H. 2016. Service quality dan kepuasan konsumen: Sstudi empiris dan implikasinya pada toko online. MIX: Jurnal Ilmiah Manajemen 6(2): 247-260.

Sutomo S, Najib M, Djohar S. 2017. Pengaruh kualitas pelayanan Lembaga Amil Zakat (LAZ) terhadap kepuasan dan loyalitas muzakki (studi kasus
LAZ PKPU Yogyakarta). Jurnal Aplikasi Bisnis dan Manajemen 3(1): 59-70. https://doi. org/10.17358/jabm.3.1.59

Umar H. 2003. Riset Pemasaran dan Perilaku Konsumen. Jakarta : Gramedia Pustaka Utama.

Wu CS, Chen TT. 2019. Building brand's value: Research on brand image, personality and identification. InternationalJournalof Management, Economics and Social Sciences (IJMESS) 8(4): 299-318. https://doi.org/10.32327/IJMESS/8.4.2019.19

Yola M dan Budianto D. 2013. Analisis kepuasan konsumen terhadap kualitas pelayanan dan harga produk pada supermarket dengan menggunakan metode importance performance analysis (IPA). Jurnal Optimasi Sistem Industri 12(12): 301309. https://doi.org/10.25077/josi.v12.n1.p301309.2013

Yulia PR, Baga LM, Djohar S. 2016. Kepuasan konsumen terhadap pelayanan apotek dan tingkat pengetahuan konsumen mengenai standar pelayanan kefarmasian yang berlaku (studi kasus di Kota Depok). Jurnal Aplikasi Bisnis dan Manajemen 2(3): 312-322.https:// doi.org/10.17358/JABM.2.3.312

Yunus U. 2016. Enhance the brand image through television commercial (Tvc): A a case study "create your chance" of Ttokopedia.com and apologizes of Bbukalapak. com. Humaniora 7(4): 569-576. https://doi.org/10.21512/humaniora. v7i4.3609 